\title{
Iptek berbasis masyarakat melalui program JIBAS (jaringan informasi bersama antar sekolah) dalam pengelolaan perpustakaan sekolah
}

\section{Alfiani Athma Putri Rosyadi ${ }^{\star}$, Adi Slamet Kusumawardana ${ }^{2}$}

1Universitas Muhammadiyah Malang, Indonesia, email: alfi rosyadi@umm.ac.id

2Universitas Muhammadiyah Malang, Indonesia, email: adikusuma@umm.ac.id

*Koresponden penulis

\section{Info Artikel}

Diajukan: 29 Des 2020

Diterima: 01 Jun 2021

Diterbitkan: 14 Jun 2021

Keywords:

JIBAS; management; library

Kata Kunci:

JIBAS; perpustakaan;

perpustakaan

\section{Lisensi:}

cc-by-sa

\begin{abstract}
Library is one of the learning resources that can be used by students to find the information needed. However, based on the result of observations obtained the fact that students are not attracted to the library because they have difficulty in finding the book they are looking for. This is because the management of books in the school still uses manual book data collection. Based on these problems, IT-based library management is one of the solutions offered. JIBAS is a network of school information systems that are integrated into assisting school management. One application that is available at JIBAS is SIMTAKA which is an application that helps schools manage data and library activities. The activity was started with the JIBAS program training by the Community Service Team. After the training, the activity continued with mentoring activities. This assistance was carried out in schools by testing the use of the JIBAS program in library management. The next activity is the implementation of the JIBAS program where partners have used the program in three months. The last activity is the reflection. In this activity, there is an exchange of information and experience during library management using the JIBAS program for three months. Suggestions for the next activity can be developed JIBAS for school finance and management.
\end{abstract}

\footnotetext{
Abstrak

Perpustakaan merupakan salah satu sumber belajar yang dapat digunakan siswa untuk mencari informasi yang dibutuhkan. Namun berdasarkan hasil observasi didapatkan fakta bahwa siswa tidak tertarik dengan perpustakaan karena kesulitan menemukan buku yang dicari. Hal ini dikarenakan pengelolaan buku di sekolah masih menggunakan pendataan buku manual. Berdasarkan permasalahan tersebut maka pengelolaan perpustakaan berbasis IT menjadi salah satu solusi yang ditawarkan. JIBAS adalah jaringan sistem informasi sekolah yang terintegrasi untuk membantu manajemen sekolah. Salah satu aplikasi yang tersedia di JIBAS adalah SIMTAKA yaitu aplikasi yang membantu sekolah dalam mengelola data dan kegiatan perpustakaan. Kegiatan diawali dengan pelatihan program JIBAS oleh Tim Pengabdian Masyarakat. Usai pelatihan, kegiatan dilanjutkan dengan kegiatan pendampingan. Pendampingan ini dilakukan di sekolah-sekolah dengan menguji pemanfaatan program JIBAS dalam pengelolaan perpustakaan. Kegiatan selanjutnya adalah implementasi program JIBAS dimana mitra sudah menggunakan program selama tiga bulan. Kegiatan terakhir adalah refleksi. Dalam kegiatan ini terjadi
} 
pertukaran informasi dan pengalaman selama pengelolaan perpustakaan menggunakan program JIBAS selama tiga bulan. Saran untuk kegiatan berikutnya dapat dikembangkan JIBAS untuk keuangan dan manajemen sekolah.

\section{PENDAHULUAN}

Pembelajaran dapat dilihat dari dua sisi, yaitu sebagai proses penyampaian materi pelajaran dan proses pengaturan lingkungan agar siswa dapat belajar (Afandi, 2013; Arifin, 2012; Pane \& Darwis Dasopang, 2017; Tafonao, 2018). Dalam proses penyampaian materi diharapkan terjadi komunikasi aktif antara guru dengan peserta didik. Media pembelajaran dan sumber belajar merupakan salah satu alternatif dalam menyampaikan materi kepada siswa (Dwijayani, 2017; Hakim, 2018; Maimunah, 2016; Tafonao, 2018; Yaumi, 2018).

Sumber belajar sebagai semua sumber (data, manusia, dan barang) yang dapat dipakai oleh pelajar sebagai suatu sumber tersendiri atau dalam kombinasi untuk memperlancar belajar (Rosyadi, 2020). Lingkungan sekitar sekolah merupakan salah satu sumber belajar yang efektif untuk digunakan dalam proses pembelajaran (Rosyadi, 2016). Lapangan sekolah, kebun sekolah, ruang kelas, kantor, kantin sekolah dan perpustakaan merupakan beberapa contoh lingkungan sekolah yang dapat dijadikan sebagai sumber belajar (Chávez Arcega, 2010; Kumar \& Nanda, 2018).

Secara sederhana, pengertian perpustakaan adalah salah satu bentuk organisasi sumber belajar yang menghimpun berbagai informasi dalam bentuk buku dan bukan buku yang dapat dimanfaatkan oleh pemakai (guru, siswa, dan masyarakat) dalam upaya mengembangkan kemampuan dan kecakapannya. Perpustakaan sekolah merupakan salah satu sumber belajar yang dapat digunakan oleh siswa untuk mencari informasi yang diperlukan (Cahyaningtyas \& Siska, 2015; Nurajizah, 2015; Puspitasari, 2016; Zohriah, 2018). Namun pada kenyataannya jarang sekali siswa mengunjungi perpustakaan sekolah dan menggunakannya sebagai sumber belajar. Berdasarkan hasil observasi diperoleh fakta bahwa siswa tidak tertarik ke perpustakaan karena sulit menelusuri buku yang dicari sehingga memerlukan waktu yang lama untuk menelusuri setiap barisan buku yang ada di rak.

Berdasarkan hasil wawancara pengelolaan perpustakaan di SDN Madyopuro 4 Malang masih menggunakan teknik yang konvensional yaitu semua buku yang masuk di data pada buku induk. Label buku yang ada disesuaikan dengan data yang ada pada buku induk. Apabila siswa mencari buku yang diinginkan harus mengurutkan kode yang ada di buku secara manual. Seringkali posisi buku juga tidak urut sehingga siswa mengalami kesulitan dalam menemukan buku yang dicari. Selain itu belum ada pendataan yang efektif untuk proses pinjam meminjam.

Pengembangan perpustakaan meliputi: 1) meningkatkan kualitas dan kuantitas koleksi buku, 2) tersedianya sarana dan prasarana, dan 3) Tersedianya sumber daya manusia. Salah satu aspek pengembangan perpustakaan yang belum terpenuhi pada SD mitra adalah ketersediaannya sarana dan prasarana terutama dalam hal pengelolaan dan manajemen buku. 
Sejalan dengan hal tersebut, diperlukan sebuah pengelolaan perpustakaan yang efektif sehingga memudahkan pihak sekolah dalam mengembangkan perpustakaan itu sendiri. Pengelolaan perpustakaan berbasis IT adalah salah satu solusi yang dapat ditawarkan (Akbar et al., 2015; Tuanakotta, 2016).

JIBAS (Jaringan Informasi Bersama Antar Sekolah) adalah sebuah jaringan sistem informasi sekolah yang terintegrasi dalam membantu pengelolaan sekolah, mengalirkan informasi, menyediakan media komunikasi dan membangun kolaborasi diantara komunitas pendidikan sekolah dari mulai mahasiswa, guru, sekolah, orang tua, pemerintah dan masyarakat umum (Akbar et al., 2015; IImiah et al., 2016; Sa'diyah et al., 2020). Salah satu aplikasi yang ada pada JIBAS yaitu SIMTAKA (Sistem Informasi Perpustakaan) yang merupakan aplikasi yang membantu sekolah untuk mengelola data dan kegiatan perpustakaan.

Di dalam aplikasi SIMTAKA terdapat pengelolaan yang praktis terkait dengan pendataan buku dan alur peminjaman buku serta alur pengembaliannya. Hal ini dapat memudahkan sekolah dalam mengelola perpustakaannya secara online dan dapat diakses dengan mudah oleh seluruh siswa. Penelitian tentang JIBAS yang di dalamnya ada SIMTAKA sudah dilakukkan antara lain yaitu penelitian Akbar et al., (2015) ; Ilmiah et al., (2016); dan Sa'diyah et al., (2020), tetapi belum ada yang menggunakan dalam perpustakaan sekolah.

Berdasarkan hasil observasi dan wawancara diperoleh fakta terkait dengan perpustakaan sekolah di SD Mitra antara lain yaitu: a) Siswa kurang tertarik menggunakan perpustakaan sebagai sumber belajar karena kesulitan dalam mencari buku yang diinginkan, b) Pengelolaan administrasi perpustakaan di sekolah masih menggunakan cara konvensional yaitu mencatat segala alur pinjam meminjam pada buku induk dan c) Pendataan koleksi buku perpustakaan masih menggunakan pelabelan manual dan peluang koleksi buku hilang cukup besar karena belum ada sistem dan alat barcode pada perpustakaan. Berdasarkan permasalahan tersebut pengabdian ini bertujuan untuk melakukan kegiatan pelatihan dan pendampingan program JIBAS pada perpustakaan di SDN Madyopuro IV Malang.

\section{METODE PELAKSANAAN}

Pelaksanaan kegiatan diawali dengan pelatihan program JIBAS oleh Tim Pengabdian. Selama pelatihan, mitra diberikan modul sehingga memudahkan dalam menerima materi yang disampaikan. Setelah pelaksanaan pelatihan dilanjutkan dengan kegiatan pendampingan. Pendampingan ini dilakukan di sekolah didampingi oleh TIM pengabdian. Kegiatan pendampingan dilakukan dengan uji coba di sekolah terkait dengan penggunaan program JIBAS dalam pengelolaan perpustakaan. Kegiatan berikutnya implementasi program JIBAS dimana mitra sudah menggunakan program tersebut di sekolah. Pada kegiatan terakhir adalah refleksi. Pada kegiatan ini, terdapat tukar menukar informasi dan pengalaman yang dialamai selama pengelolaan perpustakaan dengan menggunakan program JIBAS selama 3 bulan. Alur pelaksanaan kegiatan Ibm 
Program JIBAS dalam Pengelolaan Perpustakaan Sekolah dapat dilihat pada Gambar 1 berikut.

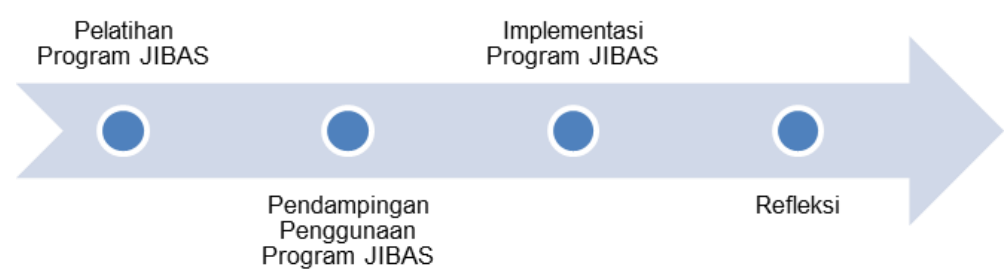

Gambar 1. Metode Pelaksanaan

\section{HASIL DAN PEMBAHASAN}

Berikut ini merupakan deskripsi IPTEK Berbasis Masyarakat Program JIBAS dalam Pengelolaan Perpustakaan Sekolah.

\section{Alur Pelaksanaan}

a. Pelatihan Program JIBAS

Kegiatan diawali dengan proses sosialisasi program pengabdian pada sekolah mitra. Selanjutnya dilakukan kesepakatan antara Tim pengabdian dan sekolah mitra terkait dengan kegiatan pelatihan program JIBAS yang akan dilakukan. Pelatihan program jibas diikuti oleh dua orang tim pengelola perpustakaan dari SDN Madyopuro 4 Malang. Selama kegiatan pelatihan, disediakan modul yang berisi tutorial program JIBAS.

Tim Mitra menghadiri acara pelatihan yang diawali dengan kegiatan sosialisasi kegiatan pengabdian. Adapun materi yang harus dipahami bagaimana menginstall program JIBAS, menggunakan aplikasinya dan mengkaitkan materi yang diperoleh dengan pengelolaan perpustakaan yang ada di sekolah masing-masing. Setelah melakukan pelatihan, diharapkan Tim Mitra dapat mengetahui secara teori dan praktek bagaimana menggunakan program JIBAS.

b. Pendampingan Penggunaan Program JIBAS

Pendampingan dilakukan dengan uji coba di sekolah terkait dengan penggunaan program JIBAS dalam pengelolaan perpustakaan. Tim pengabdi melakukan pemantauan langsung terkait dengan bagaimana alur penggunaan program di sekolah. Selama proses uji coba, tim mitra akan mendapat pendampingan secara intensif dari tim pengabdian. Pendampingan juga dilaksanakan sebagai bentuk kolaborasi tim pengabdian dan tim mitra.

Pada tahap ini, tim mitra sudah melakukan praktek uji coba penggunaan program JIBAS di sekolah. Selama kegiatan pendampingan, diharapkan tim mitra dapat menggunakan program JIBAS dengan baik. Hasil diskusi dan sharing informasi selama proses pendampingan ditulis dan dapat digunakan acuan untuk kegiatan implementasi selanjutnya. 
c. Implementasi Program JIBAS

Kegiatan implementasi di sini adalah hasil penggunaan program JIBAS yang sudah dilakukan oleh tim mitra di sekolahnya. Tim pengabdian melakukan evaluasi terkait dengan penggunaan program JIBAS oleh tim mitra selama 3 bulan. Tim mitra melaksanakan program JIBAS di perpustakaan sekolah. Hal ini dilakukan untuk mengetahui penggunaan program ini dalam periode tertentu. Hasil sharing dan diskusi yang diperoleh pada kegiatan pendampingan dapat dijadikan acuan selama kegiatan implementasi. Setelah kegiatan implementasi diharapkan diperoleh catatan kegiatan yang di dalamnya terdapat kendala atau permasalahan yang muncul selama 3 bulan uji coba di sekolah.

d. Refleksi dan tindak lanjut

Kegiatan refleksi di sini adalah diskusi yang di dalamnya terdapat sharing informasi dan solusi dari permasalahan yang sudah dituliskan pada kegiatan implementasi. Hal ini dilakukan untuk penggunaan program JIBAS. Pada kegiatan refleksi di sini tim mitra melakukan diskusi dan tukar menukar informasi dengan tim pengabdian. Hasil dari kendala yang dituliskan dalam kegiatan implementasi didiskusikan di kegiatan refleksi. Tim mitra menerima masukan dari tim pengabdi selama proses refleksi. Pada kegiatan tindak lanjut, diharapkan mitra masih mengaplikasikan program JIBAS dalam pengelolaan perpustakaan maupun untuk manajemen sekolah yang lain. Kegiatan tindak lanjut ini berlangsung secara berkala artinya tim pengabdian terus melakukan pemantauan perkembangan perpustakaan sekolah yang dilakukan mitra.

\section{Hasil dan Diskusi}

Tim pengabdian datang ke SDN Madyopuro IV yang berada di Jalan Madyopuro No 33 Kecamatan kedungkandang, Malang. Pada saat observasi awal, tim bertemu langsung dengan Kepala sekolah dan menyampaikan maksud kedatangan kami. Dari hasil observasi diperoleh data antara lain: Di sekolah terdapat dua tempat yaitu gazebo di lantai 1 sebagai ruang baca, yang di dalamnya terdapat beberapa buku bacaan yang dibawa oleh siswa sendiri. Secara teknis untuk peminjamannya tidak diatur oleh tim perpustakaan sekolah. Selain itu untuk ruangan perpustakaan sekolah itu sendiri ada di lantai 2, sejak tahun 2018 ruang perpustakaan digabung dengan ruang kelas. Hal ini dikarenakan adanya kebijakan dari dinas bahwa wajib ada ruang komputer untuk ujian berlangsung sehingga ruang perpustakaan digunakan sebagai ruang kelas. Perbincangan singkat dengan Tim dilanjutkan pada hari berikutnya karena kepala sekolah ada rapat di SD lain.

Pada pertemuan selanjutnya, tim datang lagi ke sekolah untuk melanjutkan observasi dan bertemu dengan Kepala sekolah serta Petugas perpustakaan. Pada hari ini Tim melihat langsung bagaimana kondisi dari perpustakaan serta bercakap-cakap dengan petugas 
perpustakaan. Dari hasil disuksi dengan beliau ada beberapa data yang kami peroleh

a. Perpustakaan selama ini menggunakan aplikasi hasil pengembangan dari excel dan word yang merupakan hasil pelatihan 2018 yang diadakan oleh dinas pendidikan kabupaten Malang.

b. Pendataan buku di perpustakaan masih manual dan belum menggunakan barcode.

c. Proses layanan perpustakaan dilakukan setelah jam 12 siang karena terkendala dengan ruangan perpustakaan yang digunakan sebagai ruang kelas.

d. Spesifikasi komputer yang digunakan tidak layak untuk pendataan buku dan program lain.

e. Beberapa buku masih belum dilabeli karena baru datang, dan hanya ada beberapa buku yang sudah diberi label.

Berdasarkan hasil observasi selama dua hari, hasil diskusi tim memberikan beberapa solusi sesuai dengan proposal pengabdian kami yaitu: 1) Pelatihan Program JIBAS Draft pelatihan yang berisi tutorial program JIBAS, 2) Pendampingan Penggunaan Program JIBAS, 3) Implementasi Program JIBAS serta 4) Refleksi dan tindak lanjut. Hal ini sesuai dengan tujuan program pelatihan nantinya akan memberi dampak pada masyarakat.

Tim pengabdian melakukan kunjungan ke sekolah untuk memberikan alat pindai barcode yang digunakan untuk memudahkan dalam proses pinjam meminjam. Alat pindai barcode yang kami berikan diterima sangat baik dan dicobakan kepada komputer sekolah. Dari hasil wawancara dengan petugas Perpustakaan diperoleh informasi bahwa komputer yang digunakan sekarang belum support dengan alat barcode yang ada, sehingga untuk kedepannya akan diganti dengan komputer lain oleh pihak sekolah dengan spesifikasi yang lebih baik.

\section{Pelatihan dan Pendampingan}

Sesuai dengan permintaan pihak sekolah bahwa kegiatan pengabdian dilanjutkan pada saat sekolah libur. Hal ini dilakukan agar dapat dengan leluasa dalam melakukan workshop dan pendataan perpustakaan. Dalam kegiatan pengabdian tersebut dihadiri oleh dua tim pengabdian, satu orang pustakawan dan tiga orang mahasiswa yang terlibat. Kegiatan dimulai pukul 10.00 dengan agenda pada tabel 1 berikut:

Tabel 1. Agenda Kegiatan Pengabdian

\begin{tabular}{|c|c|c|c|}
\hline No & Waktu & Uraian Kegiatan & Keterangan \\
\hline 1. & $10.00-10.30$ & $\begin{array}{l}\text { Persiapan dan pengarahan oleh tim } \\
\text { pengabdian }\end{array}$ & Pembagian tugas \\
\hline 2. & $10.30-12.00$ & Pelatihan program JIBAS oleh Tim pengabdian & $\begin{array}{l}\text { Pustakawan menerima } \\
\text { kegiatan pelatihan oleh Tim. }\end{array}$ \\
\hline 3. & $12.00-13.00$ & Ishoma & \\
\hline 4. & $13.00-15.00$ & Impelementasi program JIBAS dengan & Dibantu oleh mahasiswa \\
\hline
\end{tabular}




\begin{tabular}{|c|c|c|c|}
\hline No & Waktu & Uraian Kegiatan & Keterangan \\
\hline & & $\begin{array}{l}\text { melakukan pendataan beberapa buku yang } \\
\text { sudah diklasifikasi sebelumnya oleh } \\
\text { pustakawan }\end{array}$ & \\
\hline 5. & $15.00-15.15$ & Penutup & $\begin{array}{l}\text { Penyampaian tindak lanjut } \\
\text { oleh Tim pengabdian }\end{array}$ \\
\hline
\end{tabular}

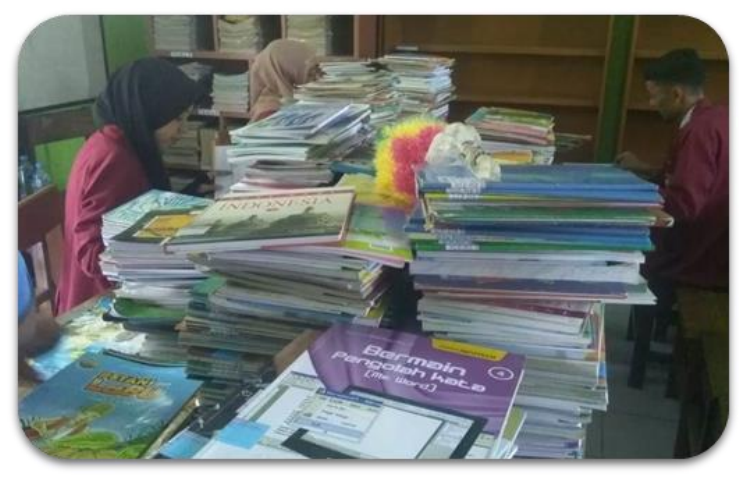

Gambar 2. Kegiatan Mengklasifikasi Buku

Mahasiswa dilibatkan dalam melakukan klasifikasi buku, karena koleksi buku SDN Madyopuro IV mencapai 1000 buku. Pengklasifikasian disesuaikan dengan jenis buku yang sudah ada pada aplikasi JIBAS. Misalnya buku agama, komputer, bahasa dll. Untuk berikutnya akan ditata pada rak yang sudah disediakan. Selanjutnya setelah melakukan instalasi program JIBAS yang disambungkan dengan alat pindai barcode. Komputer yang awalnya spesifikasinya belum mendukung kegiatan ini, ternyata diganti dengan komputer yang cukup baik. Hal ini tidak lain karena support dari Kepala SDN Madyopuro IV Malang. Hal ini sangat membantu proses pendataan buku, peminjaman dan pengembalian yang ada di SDN Madyopuro IV. Setelah melakukan kegiatan instalasi, berikutnya adalah kegiatan pelatihan program JIBAS oleh Tim pengabdian. Pustakawan juga diminta untuk mencoba melakukan pendataan menggunakan JIBAS.

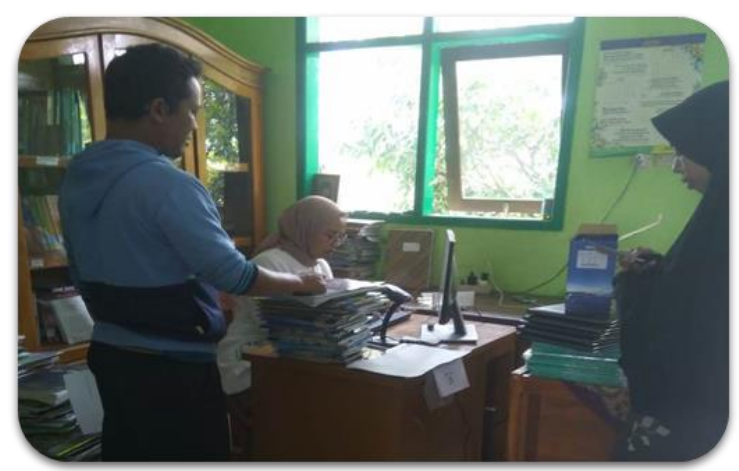

Gambar 3. Pendataan buku menggunakan JIBAS 
Di akhir kegiatan tim pengabdian menyampaikan bahwa kegiatan ini sebenarnya perlu ditindaklanjuti. Diharapkan pustakawan melanjutkan pendataan buku.

\section{Implementasi Program JIBAS}

Penggunaan program JIBAS dilakukan secara kontinu oleh pustakawan untuk mendata, melakukan print barcode dan menempel barcode pada buku. Implementasi dilakukan selama bulan Juli selama kegiatan kunjungan oleh tim pengabdian. Setelah dilakukan diskusi dilanjutkan lagi sampai kegiatan terlaksana secara maksimal. Dalam pelaksanannya, pustakawan dibantu oleh tiga orang mahasiswa. Mahasiswa membantu mengklasifikasi buku, mengeprint barcode dan menempel. Untuk pendataan dilakukan sendiri oleh pustakawan setiap hari. Berikut ini adalah tampilan pada saat penjelasan implementasi JIBAS.

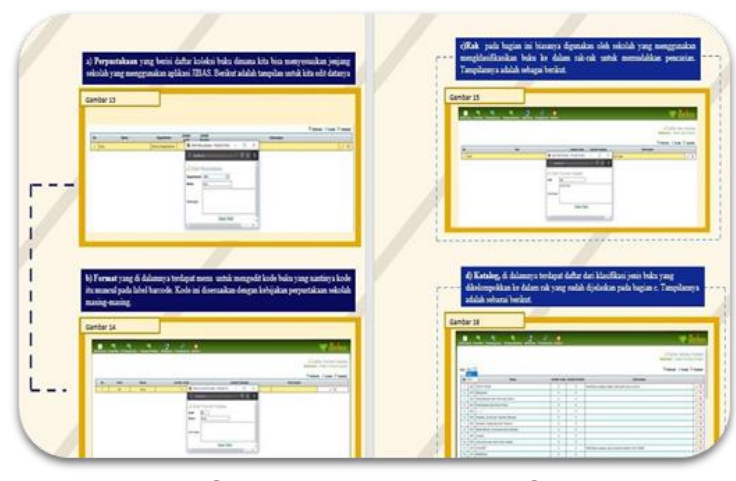

Gambar 4. Tampilan JIBAS

\section{Refleksi dan Tindak Lanjut}

Selama implementasi ada sedikit kendala yaitu pustakawan lupa dengan cara print barcode serta terkait dengan tidak adanya printer di perpustakaan. Hal ini sudah diberikan solusi yaitu pemberian bimbingan online via WA dalam print barcode. Untuk kendala printer, pihak sekolah bisa memfasilitasi selama beberapa hari dalam pendataan buku.

\section{KESIMPULAN}

Berdasarkan kegiatan pengabdian sudah dilakukan beberapa kegiatan yaitu: 1) Pelatihan Program JIBAS Draft pelatihan yang berisi tutorial program JIBAS, 2) Pendampingan Penggunaan Program JIBAS, 3) Implementasi Program Jibas serta 4) Refleksi dan tindak lanjut. Kegiatan pelaksanaan JIBAS ini berjalan dengan baik dan mendapatkan respon bagus dari pustakawan, sehingga diharapkan ada pelatihan lanjutan program JIBAS. Hasil pencapaian dari kegiatan pengabdian ini adalah keterlaksanaan program perpustakaan dengan menggunakan JIBAS oleh pustakawan. Selain 
itu program pendataan buku dan pinjam meminjam juga berjalan dengan baik dan terstruktur.

Untuk saran dan tindak lanjut pada kegiatan pengabdian berikutnya bisa dikembangkan aplikasi JIBAS yang lain misalnya pendataan siswa, dana sekolah dan manajemen sekolah. Saran untuk kegiatan berikutnya dapat dikembangkan JIBAS untuk keuangan dan manajemen sekolah.

\section{UCAPAN TERIMA KASIH}

Ucapan terima kasih kami sampaikan kepada DPPM Universitas Muhammadiyah Malang yang sudah memberikan dana untuk kegiatan pengabdian kepada masyarakat kepada tim kami.

\section{DAFTAR RUJUKAN}

Afandi, M. (2013). Model dan Motode Pembelajaran. In Unissula press.

Akbar, R., Rahmawati, T., \& . A. (2015). Implementasi Sistem Informasi Akademik Menggunakan Aplikasi Jibas pada SMA Negeri 9 Padang. Jurnal Nasional Teknologi Dan Sistem Informasi, 1(1), 36-41. https://doi.org/10.25077/teknosi.v1i1.2015.36

Arifin, Z. (2012). Evaluasi pembelajaran. Direktorat Jenderal Pendidikan Islam Kementerian Agama RI.

Cahyaningtyas, R., \& Siska, I. (2015). Perancangan Sistem Informasi Perpustakaan Pada Smp Negeri 3 Tulakan, Kecamatan Tulakan Kabupatean Pacitan. Indonesian Journal on Networking and Security, 4(2), 15-20. https://doi.org/10.1123/ijns.v4i2.1308

Chávez Arcega, M. (2010). Instructional technology and media for learning. Revista Mexicana de Investigación Educativa.

Dwijayani, N. M. (2017). Pengembangan Media Pembelajaran ICARE. Kreano, Jurnal Matematika Kreatif-Inovatif, 8(2), 126-132. https://doi.org/10.15294/kreano.v8i2.10014

Hakim, L. (2018). Pengembangan Media Pembelajaran PAI Berbasis Augmented Reality. Lentera Pendidikan: Jurnal IImu Tarbiyah Dan Keguruan, 21(1), 59-72. https://doi.org/10.24252/lp.2018v21n1i6

Kumar, V., \& Nanda, P. (2018). Social Media in Higher Education: A Framework for Continuous Engagement. International Journal of Information and Communication Technology Education (IJICTE), 15(1), 97-108. https://doi.org/10.4018/ijicte.2019010107

Maimunah, M. (2016). Metode Penggunaan Media Pembelajaran. Al-Afkar: Jurnal Keislaman \& Peradaban, 5(1), 1-24. https://doi.org/10.28944/afkar.v5i1.107

Nurajizah, S. (2015). Sistem Informasi Perpustakaan Berbasis WEB dengan Metode Prototype: Studi Kasus Sekolah Islam Gema Nurani Bekasi. Seminar Nasional Inovasi Dan Tren (SNIT), 214-219.

Pane, A., \& Darwis Dasopang, M. (2017). Belajar dan Pembelajaran. FITRAH:Jurnal Kajian Ilmu-IImu Keislaman, 3(2), 333-352. https://doi.org/10.24952/fitrah.v3i2.945

Puspitasari, D. (2016). Sistem Informasi Perpustakaan Sekolah Berbasis 
Web. Jurnal Pilar Nusa Mandiri, 12(2), 227-240. http://ejournal.nusamandiri.ac.id/ejurnal/index.php/pilar/article/view/181

Putri Rosyadi, A. A. (2016). Pengembangan Modul Pembelajaran Menggunakan Pendekatan Penemuan Terbimbing Pada Matakuliah Kalkulus. Jurnal Pendidikan Matematika (JPM), 2(1), 11-16. https://doi.org/10.33474/jpm.v2i1.201

Rosyadi, A. A. P. (2020). Development of interactive mathematic stories (BuCIM) based on dienes theory. Math Didactic: Jurnal Pendidikan Matematika, 6(2), 235-243. https://doi.org/10.33654/math.v6i2.678

Sa'diyah, Z., Aziz, K. E., Dardiri, M. H., \& Yaqin, M. A. (2020). Pengembangan Web Service Sistem Informasi Sekolah. Jurasik (Jurnal Riset Sistem Informasi Dan Teknik Informatika), 5(1), 154-165. https://doi.org/10.30645/jurasik.v5i1.180

Tafonao, T. (2018). Peranan Media Pembelajaran Dalam Meningkatkan Minat Belajar Mahasiswa. Jurnal Komunikasi Pendidikan, 2(2), 103-114. https://doi.org/10.32585/jkp.v2i2.113

Triwiyono, D. A., \& Meirawan, D. (2013). Implementasi Sistem Informasi Manajemen Akademik Berbasis Teknologi Informasi di Sekolah Dasar. Jurnal Administrasi Pendidikan UPI, 17(1), 61-72. https://doi.org/10.17509/jap.v17i1.6433

Tuanakotta, Y. M. (2016). Implementasi Sistem Informasi Akademik pada

Sekolah Dasar Negeri Teladan Ambon Menggunakan Aplikasi Jaringan Informasi Bersama Antar Sekolah. Universitas Kristen Satya Wacana Salatiga.

Yaumi, M. (2018). Media dan Teknologi Pembelajaran. In Jakarta.

Zohriah, A. (2018). Manajemen Perpustakaan Sekolah/Madrasah. Tarbawi: Jurnal Keilmuan Manajemen Pendidikan, 4(2), 159-170. https://doi.org/10.32678/tarbawi.v4i02.1228 